\title{
Statistical optimization of process variables by response surface methodology to enhance phenol degradation by Pseudomonas putida (NCIM 2102)
}

\author{
Velluru Sridevi ${ }^{{ }^{*}}$, Chandana Lakshmi Veera Venkata Mahanti ${ }^{1}$, \\ Swamy Venkata Narasimha Adimadhyam², Narasimha Rao Medicherla ${ }^{3}$
}

${ }^{1^{*}}$ Centre for Biotechnology, Department of Chemical Engineering, Andhra University, Visakhapatnam, India;
${ }^{2}$ Department of Biotechnology, Jawaharlal Nehru Technological University, Anantapur, India;
${ }^{3}$ Al-Ameer College of Engineering and Information Technology, College of Engineering, Visakhapatnam, India.
E-mail: ${ }^{*}$ vellurusridevi@yahoo.co.in; mahantilakshmi@yahoo.com; avnswamy@rediffmail.com; mnrmd_au@yahoo.com

Received 3 December 2010; revised 9 May 2011; accepted 6 July 2011.

\begin{abstract}
Removal efficiency of phenol from aqueous solutions was determined using Pseudomonas putida (NCIM 2102). Experiments were made as a function of $\mathrm{pH}(4$ - 9), temperature $\left(28^{\circ} \mathrm{C}-36^{\circ} \mathrm{C}\right)$, and agitation speed (100 - 200 rpm). Optimization of these three process parameters for phenol degradation was studied. Statistically designed experiments using response surface methodology was used to get more information about the significant effects and the interactions between these three parameters. A $2^{3}$ full-factorial central composite design was employed for experimental design and for analysis of the results. A second order polynomial regression model, has been developed using the experimental data. It was found that the degrading potential of $P$. putida (NCIM 2102) was strongly affected by the variations in $\mathbf{p H}$, temperature and agitation speed. The experimental values were in good agreement with the predicted values and the correlation coefficient was found to be 0.9871 . The optimum process conditions for maximizing phenol degradation were recognized as follows: $\mathrm{pH}$ (7.49), temperature $\left(29.99^{\circ} \mathrm{C}\right)$, and agitation speed $(138.89)$ rpm.
\end{abstract}

Keywords: Biodegradation of Phenol; P. putida (NCIM 2102); Central Composite Design; Correlation Coefficient

\section{INTRODUCTION}

Nowadays, contamination of the environment by hazardous and toxic chemicals is being considered as one of the major problems facing by the industrialized nations
[1]. Phenol and its higher molecular homologues are important environmental pollutants [2], which attracted public attention due to its presence in ground water, rivers and drinking waters [3]. It was also listed as a priority pollutant by the USEPA [4,5]. Acute exposure to phenol and its quinone analogues is known to cause skin irritation, kidney damage, gastrointestinal discomfort and headaches. Aesthetically, this compound also poses a nuisance with detectable taste and odors in water at concentrations as low as $1-8 \mathrm{mg} \cdot \mathrm{l}^{-1}$ [6]. Most of the countries specify the maximum allowable concentration of phenol in the effluent streams to be less than $1 \mathrm{mg} \cdot \mathrm{l}^{-1}$ [5]. Phenol and phenolic compounds of high concentrations can be found in aqueous effluents from various industries such as oil refineries, petrochemical plants, ceramic plants, steel plants, coal conversion processes, phenol resin industries and pharmaceutical industries [7]. Due to its toxicity, hazardous character and an increasing social concern on environment, the discharge of such compounds in the environment has become more restrict. Phenolic wastes are treated by several physico-chemical methods like ozonization, adsorption, reverse osmosis, electrolytic oxidation, $\mathrm{H}_{2} \mathrm{O}_{2}$, photocatalysis etc. [8]. But all the above methods have their own limitations $[3,9]$. Hence the realization of the high cost of phenol waste treatment by physico-chemical methods has opened the door for the investigation of new methods. Biological treatment an alternative method is versatile, inexpensive $[10,11]$, receiving the most attention due to its environmentally friendly approach due to their high biodegradation abilities. If properly designed and operated, biological processes can realize total oxidation of organic matter so that there can be no sludge's that must be eradicated as a result of treatment [12].

Microbial degradation of phenol has been actively 
studied and these studies have shown that the phenol can be aerobically degraded by wide variety of fungi and bacterial cultures such as Candida tropicalis [13-15], Acinetobacter calcoaceticus [16], Alcaligenes eutrophus $[17,18]$, P.putida [19,20] and Burkholderia cepacia G4 $[21,22]$. It has been demonstrated that treatment of small volumes of toxic compounds at the point of emission using specific microbial strains allows a higher control over the process and higher removal efficiencies [23]. Thus optimization of process variables is recognized to be an essential aspect of successful fermentation. Temperature exerts an important regulatory influence on the rate of metabolism. The effects of oxygen supply vary from species to species. In addition, oxygen mass transfer is aided by agitation rates that create turbulence and shear forces in the cultivation system causing significant influences on the growth rate and product formation [24].

Our main goals were to find out 1) the effect of $\mathrm{pH} ; 2$ ) the effect of temperature; 3 ) the effect of agitation speed on the biodegradation of phenol by $P$. putida (NCIM 2102) using both the classical method of optimization that involves varying the level of one parameter at a time over a certain range while holding the rest of the variables constant and statistical optimization technique for multivariable effect.

\section{DESIGN OF EXPERIMENTS}

Response surface methodology is an empirical modelization technique derived to the evaluation of the relationship of a set of controlled experimental factors and observed results. It requires a prior knowledge of the process to achieve statistical model [25-28]. Basically this optimization of process involves three major steps, which are, performing the statistically designed experiments, estimating the coefficients in a mathematical model and predicting the response and checking the adequacy of the model.

$$
Y=f\left(X_{1}, X_{2}, X_{3}, \cdots, X_{k}\right)
$$

The true relationship between $Y$ and $X_{k}$ may be complicated and, in most cases, it is unknown, however, a second-degree quadratic polynomial can be used to represent the function in the range of interest;

$$
\begin{aligned}
Y= & R_{0}+\sum_{i=1}^{k} R_{i} X_{i}+\sum_{i=1}^{k} R_{i i} X_{i}^{2} \\
& +\sum_{i=1, i<j}^{k-1} \sum_{j=2}^{k} R_{i j} X_{i} X_{j}+\varepsilon
\end{aligned}
$$

where $X_{1}, X_{2}, X_{3}, \cdots, X_{k}$ are the input variables which affect the response $Y, R_{0}, R_{i}, R_{i i}$ and $R_{i j}(i=1-k, j=1-$ $k$ ) are the known parameters, $\varepsilon$ is the random error. A second-order model is designed such that variance of $Y$ is constant for all points equidistant from the centre of the design;

$$
X_{i}=\left(\frac{X_{i}-X_{0}}{\Delta X_{i}}\right)
$$

where $X_{i}$ is the coded value, $X_{0}$ is the actual value at the center point and $\Delta X_{i}$ is the step change value. The parameters and their values (in brackets) were three levels, like $\mathrm{pH}(4-9)$, temperature $\left(28^{\circ} \mathrm{C}, 30^{\circ} \mathrm{C}, 32^{\circ} \mathrm{C}, 34^{\circ} \mathrm{C}\right.$, $\left.36^{\circ} \mathrm{C}\right)$, agitation speed $(100,120,140,160,180,200$ $\mathrm{rpm}$ ), at constant phenol concentration $0.100 \mathrm{~g} \cdot \mathrm{l}^{-1}$. This also enabled the identification of significant effects of interactions for the batch studies. In system involving three significant independent variables $X_{1}, X_{2}$, and $X_{3}$, the mathematical relationship of the response of these variables can be approximated by quadratic (second degree) polynomial equation;

$$
\begin{aligned}
y= & b_{0}+b_{1} x_{1}+b_{2} x_{2}+b_{3} x_{3}+b_{11} x_{1}^{2}+b_{22} x_{2}^{2} \\
& +b_{33} x_{3}^{2}+b_{12} x_{1} x_{2}+b_{13} x_{1} x_{3}+b_{23} x_{2} x_{3}
\end{aligned}
$$

where $Y$ is the predicted value, $b_{0}$ is the constant, $X_{1}$ is the $\mathrm{pH}, X_{2}$ is the temperature, $X_{3}$ is the agitation speed, $b_{1}, b_{2}$ and $b_{3}$ are linear coefficients, $b_{12}, b_{23}$ and $b_{13}$ are cross product coefficients and $b_{11}, b_{22}$ and $b_{33}$ are quadratic coefficients. The low, middle and high levels of each variable were designated as $-1,0$, and +1 respectively, as given in Table 1. A total of 20 runs were necessary to estimate the coefficients of the model using multiple linear regressions. The design of experiments was carried out for analysis using the Statistica 6.0 version.

\section{MATERIALS AND METHODS}

\subsection{Microorganism}

The microorganism P.putida (NCIM 2102) was procured from culture collection NCL, Pune. The microorganism was maintained on beef extract: $1.0 \mathrm{~g} \cdot \mathrm{l}^{-1}$; yeast extract: $2.0 \mathrm{~g} \cdot 1^{-1}$; peptone: $5.0 \mathrm{~g} \cdot \mathrm{l}^{-1}$; sodium chloride: $5.0 \mathrm{~g} \cdot \mathrm{l}^{-1}$ and agar: $20.0 \mathrm{~g} \cdot 1^{-1}$. The medium was adjusted to $\mathrm{pH} 7.0$ by $1 \mathrm{~N}$ sodium hydroxide. It was stored at $4^{\circ} \mathrm{C} \pm 1^{\circ} \mathrm{C}$ for further use.

Table 1. Optimization of medium components and the conditions of fermentation for the degradation of phenol by P.putida (NCIM 2102).

\begin{tabular}{cccccc}
\hline & \multicolumn{5}{c}{ Coded levels } \\
\cline { 2 - 6 } Variables & -1.682 & -1 & 0 & 1 & 1.682 \\
\hline $\mathrm{pH}\left(X_{1}\right)$ & 5.32 & 6 & 7 & 8 & 8.68 \\
$\begin{array}{c}\text { Temperature }\left({ }^{\circ} \mathrm{C}\right),\left(X_{2}\right) \\
\begin{array}{c}\text { Agitation Speed } \\
(\mathrm{rpm}),\left(X_{3}\right)\end{array}\end{array}$ & 26.64 & 28 & 30 & 32 & 33.36 \\
\hline
\end{tabular}




\subsection{Optimization Studies}

The physical parameters namely $\mathrm{pH}$ : $\left(4-9 \mathrm{~g} \cdot \mathrm{l}^{-1}\right)$; temperature: $\left(28^{\circ} \mathrm{C}, 30^{\circ} \mathrm{C}, 32^{\circ} \mathrm{C}, 34^{\circ} \mathrm{C}, 36^{\circ} \mathrm{C}\right)$ and agitation speed: $(100,120,140,160,180,200 \mathrm{rpm})$ at constant $0.100 \mathrm{~g} \cdot \mathrm{l}^{-1}$ phenol concentration were studied in the minimal medium composed of dihydrogen potassium phosphate: $1.5 \mathrm{~g} \cdot \mathrm{l}^{-1}$; potassium dihydrogen phosphate: $0.5 \mathrm{~g} \cdot \mathrm{l}^{-1}$; ammonium sulfate: $0.5 \mathrm{~g} \cdot \mathrm{l}^{-1}$; sodium chloride: $0.5 \mathrm{~g} \cdot \mathrm{l}^{-1}$; sodium sulfate: $3.0 \mathrm{~g} \cdot \mathrm{l}^{-1}$; yeast extract: $2.0 \mathrm{~g} \cdot \mathrm{l}^{-1}$; glucose: $0.5 \mathrm{~g} \cdot \mathrm{l}^{-1}$; ferrous sulfate: $0.002 \mathrm{~g} \cdot \mathrm{l}^{-1}$ and calcium chloride: $0.002 \mathrm{~g} \cdot \mathrm{l}^{-1}$ by P.putida (NCIM 2102) for the maximum degradation of phenol. Samples were withdrawn at regular intervals for phenol determination. From the above experiments the range of $\mathrm{pH}$, temperature, and agitation speed were chosen for further optimization of the design.

\subsection{Design of Experiments}

To optimize the range of experiments the $2^{3}$ full-factorial Central Composite Design (CCD) was applied. The range and the levels of the process variables under study are given in Table 1: $\mathrm{pH}(6-8)$, temperature $\left(28^{\circ} \mathrm{C}, 30^{\circ} \mathrm{C}\right.$ and $\left.32^{\circ} \mathrm{C}\right)$ and agitation speed $(130,140$ and $150 \mathrm{rpm})$ which served as critical variables $X_{1}, X_{2}$ and $X_{3}$ respectively. The actual design of experiments is given in Table 2 for each experiment.

\subsection{Estimation of Phenol}

Phenol was determined quantitatively by the Spectrophotometric method (DR/4000 V, Hach) using 4-amino antipyrine as the color reagent $\left(\lambda_{\max }: 500 \mathrm{~nm}\right)$ according to standard methods of analysis [29].

\section{RESULTS AND DISCUSSION}

P.putida (NCIM 2102) was inoculated into minimal salt medium at different $\mathrm{pH}$, temperature and agitation speed.
The maximum percentage of phenol degradation was observed at $\mathrm{pH}(7)$, temperature $\left(30^{\circ} \mathrm{C}\right)$ and agitation speed (140 rpm) as shown in Figures 1-3. The optimum values of (Figures 1-3), $\mathrm{pH}(6-8)$, temperature $\left(28^{\circ} \mathrm{C}\right.$, $30^{\circ} \mathrm{C}$ and $\left.32^{\circ} \mathrm{C}\right)$ and agitation speed $(130,140$ and 150 rpm) were determined using CCD. Using the results of the experiments, the following second order polynomial equation giving the percentage phenol degradation as a function of $\mathrm{pH}\left(X_{1}\right)$, temperature $\left(X_{2},{ }^{\circ} \mathrm{C}\right)$ and agitation speed $\left(X_{3}, \mathrm{rpm}\right)$ was obtained by using Statistica 6.0 version.

$$
\begin{aligned}
y= & -918.346+22.952 X_{1} 29.584 X_{2}+6.962 X_{3} \\
& -1.794 X_{1}^{2}-0.595 X_{2}^{2}-0.029 X_{3}^{2} \\
& +0.155 X_{1} X_{2}+0.036 X_{2} X_{3}-0.005 X_{1} X_{3}
\end{aligned}
$$

\begin{tabular}{|c|c|c|c|c|c|c|}
\hline \multirow[b]{2}{*}{$\begin{array}{l}\text { Experiment } \\
\text { number }\end{array}$} & \multicolumn{2}{|c|}{$\mathrm{pH}$} & \multicolumn{2}{|c|}{ Temperature } & \multicolumn{2}{|c|}{ Agitation Speed } \\
\hline & Code & Value & Code & $\begin{array}{l}\text { Value } \\
\left({ }^{\circ} \mathrm{C}\right)\end{array}$ & Code & $\begin{array}{l}\text { Value } \\
(\mathrm{rpm})\end{array}$ \\
\hline 1 & -1 & 6 & -1 & 28 & -1 & 130 \\
\hline 2 & -1 & 6 & -1 & 28 & +1 & 150 \\
\hline 3 & -1 & 6 & +1 & 32 & -1 & 130 \\
\hline 4 & -1 & 6 & +1 & 32 & +1 & 150 \\
\hline 5 & +1 & 8 & -1 & 28 & -1 & 130 \\
\hline 6 & +1 & 8 & -1 & 28 & +1 & 150 \\
\hline 7 & +1 & 8 & +1 & 32 & -1 & 130 \\
\hline 8 & +1 & 8 & +1 & 32 & +1 & 150 \\
\hline 9 & -1.682 & 5.32 & 0 & 30 & 0 & 140 \\
\hline 10 & +1.682 & 8.68 & 0 & 30 & 0 & 140 \\
\hline 11 & 0 & 7 & -1.682 & 26.64 & 0 & 140 \\
\hline 12 & 0 & 7 & +1.682 & 33.36 & 0 & 140 \\
\hline 13 & 0 & 7 & 0 & 30 & -1.682 & 123.18 \\
\hline 14 & 0 & 7 & 0 & 30 & +1.682 & 156.82 \\
\hline 15 & 0 & 7 & 0 & 30 & 0 & 140 \\
\hline 16 & 0 & 7 & 0 & 30 & 0 & 140 \\
\hline 17 & 0 & 7 & 0 & 30 & 0 & 140 \\
\hline 18 & 0 & 7 & 0 & 30 & 0 & 140 \\
\hline 19 & 0 & 7 & 0 & 30 & 0 & 140 \\
\hline 20 & 0 & 7 & 0 & 30 & 0 & 140 \\
\hline
\end{tabular}

Table 2. The CCD matrix employed for the optimization of medium components and the conditions of fermentation.

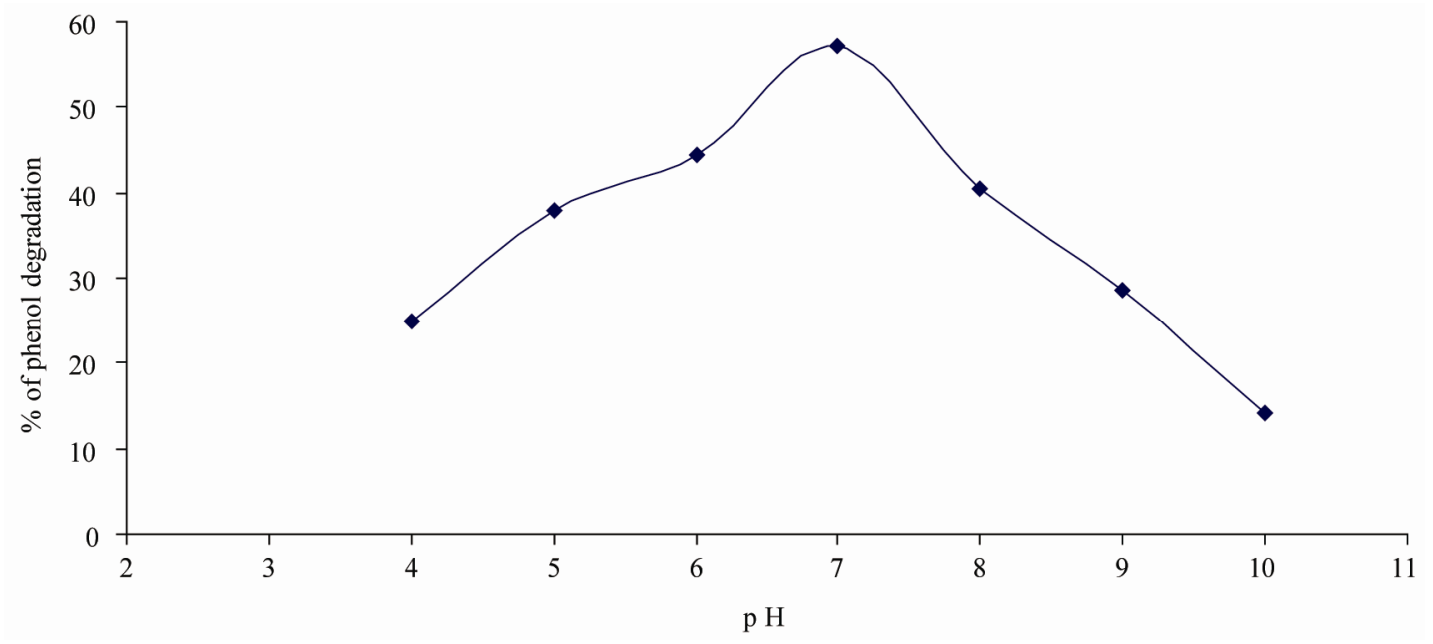

Figure 1. Optimum $\mathrm{pH}$ for phenol degradation. 


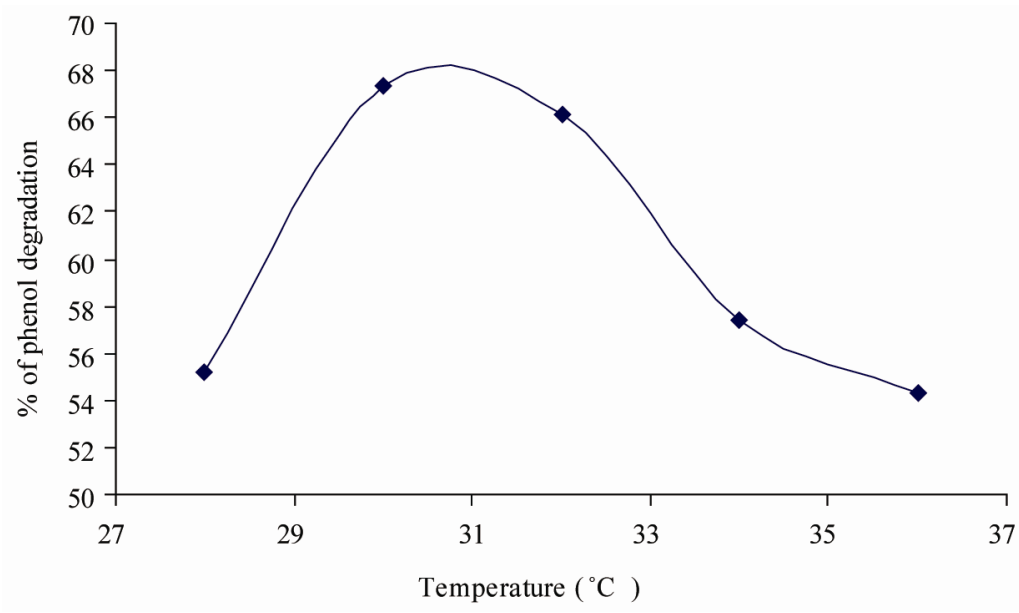

Figure 2. Optimum temperature for phenol degradation.

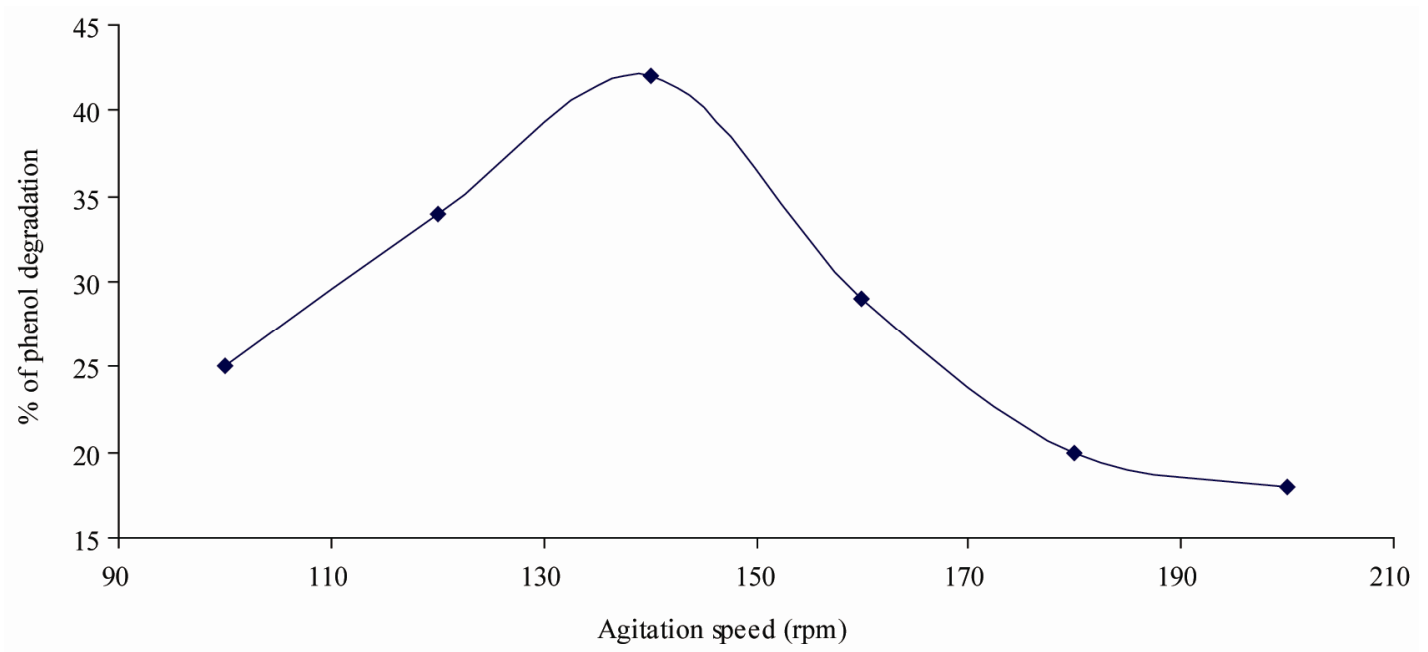

Figure 3. Optimum agitation speed for phenol deradation.

The predicted values of percentage phenol degradation using the above equation are given in Table $\mathbf{3}$ along with experimental values.

The coefficients of the regression model (Eq.5) calculated are listed in Table 4, in which they contain three linear, three quadratic and three interaction terms and one block term. The significance of each coefficient in Eq.5 was determined by student's $t$-test and $p$-values which were also listed in Table 4. The larger the magnitude of the t-value and smaller the p-value, the more significant is the corresponding coefficient. This implies that the linear and quadratic effects of $\mathrm{pH}$, temperature and agitation speed were highly significant as is evident from their respective $p$-values. The interaction effect of temperature and agitation speed was found to be significant $(p \leq 0.05)$. The remaining two interaction terms i.e. $\mathrm{pH} \times$ temperature and agitation speed $\times \mathrm{pH}$ were found to be insignificant $(p>0.05)$ which were also presented in Table 4.

The parity plot (Figure 4) showed a satisfactory correlation between the experimental and predicted values (obtained from Eq.5) of percentage phenol degradation, wherein, the points cluster around the diagonal line which indicated the optimal fit of the model, since the deviation between the experimental and predicted values was minimal.

The results of the second order response surface model fitting in the form of Analysis of Variance (ANOVA) were given in Table 5. It is required to test the significance and adequacy of the model. The Fisher variance ratio, the $F$-value $\left(=S_{r}^{2} / S_{e}^{2}\right)$, is a statistically valid measure of how well the factors describe the variation in the data about its mean. The greater the $F$-value is from unity, the more certain it is that the factors explain adequately the variation in the data about its mean, and the estimated factor effects are real. The ANOVA of the regression 
Table 3. CCD matrix showing real values along with the experimental values of percentage phenol degradation.

\begin{tabular}{cccccc}
\hline \multirow{2}{*}{ Run } & $X_{1}$ & $X_{2}$ & $X_{3}$ & \multicolumn{2}{c}{ \% Phenol degradation } \\
\cline { 5 - 6 } & & & & Experimental & Predicted \\
\hline 1 & 6 & 28 & 130 & 87.57 & 87.1215 \\
2 & 6 & 28 & 150 & 84.47 & 84.5813 \\
3 & 6 & 32 & 130 & 85.49 & 84.8932 \\
4 & 6 & 32 & 150 & 85.34 & 85.2030 \\
5 & 8 & 28 & 130 & 90.48 & 90.1140 \\
6 & 8 & 28 & 150 & 87.27 & 87.3638 \\
7 & 8 & 32 & 130 & 89.74 & 89.1257 \\
8 & 8 & 32 & 150 & 89.28 & 89.2255 \\
9 & 5.32 & 30 & 140 & 85.85 & 86.2451 \\
10 & 8.68 & 30 & 140 & 91.82 & 92.1377 \\
11 & 7 & 26.64 & 140 & 87.57 & 87.6903 \\
12 & 7 & 33.36 & 140 & 86.79 & 87.3824 \\
13 & 7 & 30 & 123.18 & 86.18 & 87.1417 \\
14 & 7 & 30 & 156.82 & 85.34 & 85.0893 \\
15 & 7 & 30 & 140 & 94.21 & 94.2541 \\
16 & 7 & 30 & 140 & 93.96 & 94.2541 \\
17 & 7 & 30 & 140 & 94.28 & 94.2541 \\
18 & 7 & 30 & 140 & 94.58 & 94.2541 \\
19 & 7 & 30 & 140 & 93.83 & 94.2541 \\
20 & 7 & 30 & 140 & 94.79 & 94.2541 \\
\hline & & & & &
\end{tabular}

Table 4. Coefficients, $t$-statistics and significance probability of the model.

\begin{tabular}{|c|c|c|c|c|c|}
\hline Term & Coefficient & Value & $\begin{array}{l}\text { Standard } \\
\text { error of } \\
\text { coefficient }\end{array}$ & $t$-value & $p$-value \\
\hline Constant & $b_{0}$ & -918.346 & 71.99615 & -12.7555 & $0.000000 *$ \\
\hline $\mathrm{pH}$ & $b$ & 22.952 & 4.73834 & 4.8 & $0.000678^{*}$ \\
\hline Temperature & $b_{2}$ & 29.584 & 2.81038 & 10.5267 & $0.000001^{*}$ \\
\hline $\begin{array}{l}\text { Agitation } \\
\text { speed }\end{array}$ & $b_{3}$ & 6.962 & 0.54787 & 12.7072 & $0.000000^{*}$ \\
\hline $\mathrm{pH} \times \mathrm{pH}$ & $b_{11}$ & -1.794 & 0.15349 & -11.6864 & $0.000000^{*}$ \\
\hline $\begin{array}{l}\text { Temperature } \\
\times \text { tempera- } \\
\text { ture }\end{array}$ & $b_{22}$ & -0.595 & 37 & -15.5066 & 0.0 \\
\hline $\begin{array}{l}\text { Agitation } \\
\text { speed } \times \\
\text { agitation } \\
\text { speed }\end{array}$ & $b_{33}$ & -0.029 & 0.00153 & -18.7779 & $0.000000^{*}$ \\
\hline $\begin{array}{l}\mathrm{pH} \times \text { tem- } \\
\text { perature }\end{array}$ & $b_{12}$ & 0.155 & 0.10284 & 1.5072 & 0.162673 \\
\hline $\begin{array}{c}\text { Temperature } \\
\times \text { agitation } \\
\text { speed }\end{array}$ & $b_{23}$ & 0.036 & 0.01028 & 3.4642 & $0.006080^{*}$ \\
\hline $\begin{array}{l}\text { Agitation } \\
\text { speed } \times \mathrm{pH}\end{array}$ & $b_{31}$ & -0.005 & 0.02057 & -0.2553 & 0.803698 \\
\hline \multicolumn{6}{|c|}{ * Significant $(p \leq 0.05)$} \\
\hline
\end{tabular}

model demonstrates that the model is highly significant, as is evident from the Fisher's $F$-test $\left(F_{\text {model }}=85.54974\right)$ and a very low probability value $\left(P_{\text {model }}>F=0.000000\right)$.

The goodness of the fit of the model was checked by

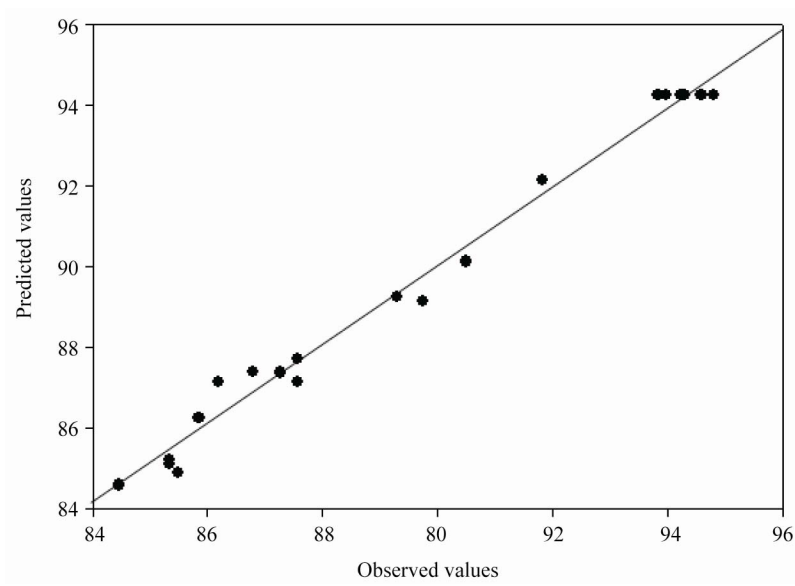

Figure 4. Parity plot showing the distribution of experimental vs. predicted values of percentage phenol degradation.

Table 5. ANOVA for the entire quadratic model.

\begin{tabular}{cccccc}
\hline $\begin{array}{c}\text { Source of } \\
\text { variation }\end{array}$ & $\begin{array}{c}\text { Sum of } \\
\text { squares } \\
\text { (SS) }\end{array}$ & $\begin{array}{c}\text { Degree of } \\
\text { freedom } \\
\text { (d.f.) }\end{array}$ & $\begin{array}{c}\text { Mean } \\
\text { squares } \\
\text { (MS) }\end{array}$ & $F$-value & Probe $>$ F \\
\hline Regression & 260.5647 & 9 & 28.95164 & 85.54974 & 0.000000 \\
Residual & 3.3842 & 10 & 0.33842 & & \\
Total & 263.9489 & 19 & & & \\
& & & & & \\
& $R^{2}=0.98717863 ;$ Adjusted $R^{2}=0.97563939$ & \\
\hline
\end{tabular}

the determination coefficient $\left(R^{2}\right)$. The $R^{2}$ value provides a measure of how much variability in the observed response values can be explained by the experimental variables and their interactions. The $R^{2}$ value is always between 0 and 1 . The closer the $R^{2}$ value is to 1 , the stronger the model is and the better it predicts the response. In this case, the value of the determination coefficient $\left(R^{2}=0.9871\right)$ indicates that $98.71 \%$ of the variability in the response could be explained by the model. In addition, the value of the adjusted determination coefficient (Adj $R^{2}=0.9756$ ) is also very high to advocate for a high significance of the model.

Figures 5-7 represent the contour plots for the optimization of physical conditions of percentage phenol degradation. The effect of the $\mathrm{pH}$ and temperature on the percentage phenol degradation was shown in Figure 5. An increase in the $\mathrm{pH}$ with temperature up to the optimum point increased the percentage phenol degradation to a maximum level and a further increase in the $\mathrm{pH}$ with temperature the trend is reversed.

The interaction effect of the temperature and agitation speed on the percentage phenol degradation is shown in Figure 6. An increase in the temperature with agitation speed increased the percentage phenol degradation gradu- 


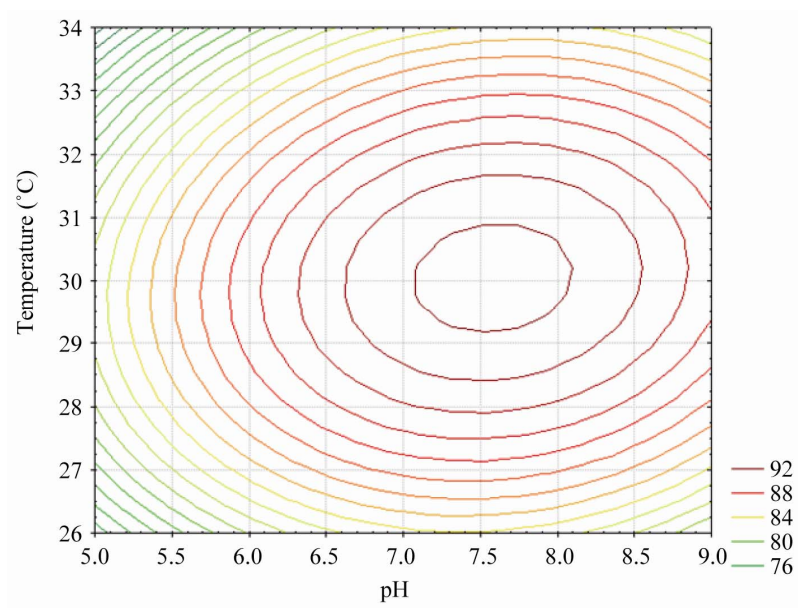

Figure 5. Contour plot of $\mathrm{pH}$ vs. temperature on $\%$ phenol degradation (agitation speed was kept constant at $140 \mathrm{rpm}$ ).

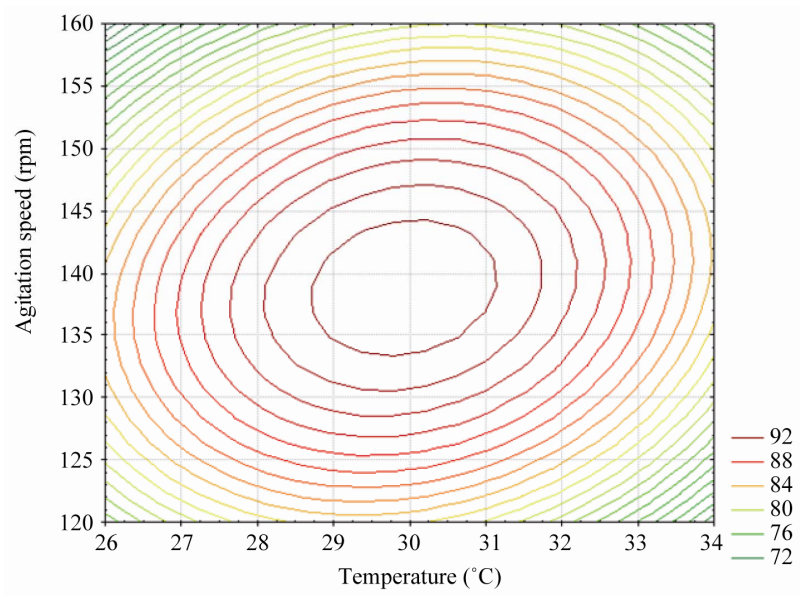

Figure 6. Contour plot of temperature vs. agitation speed on $\%$ phenol degradation ( $\mathrm{pH}$ was kept constant at 7).

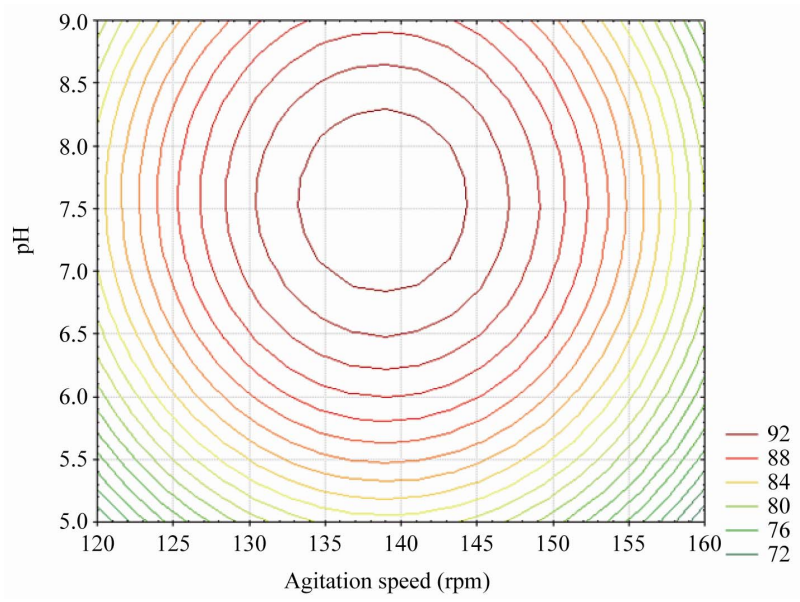

Figure7. Contour plot of agitation speed vs. $\mathrm{pH}$ on $\%$ phenol degradation (temperature was kept constant at $30^{\circ} \mathrm{C}$ ).

ally but at a higher agitation speed and temperature the trend is reversed. The optimum for maximum percentage phenol degradation lies near the center point of the temperature and agitation speed.

A similar effect on the response was observed for the agitation speed at any level of the $\mathrm{pH}$. An increase in the agitation speed with $\mathrm{pH}$ up to the optimum point increased the percentage phenol degradation to maximum level and a further increase in the agitation speed with $\mathrm{pH}$ decreased the percentage phenol degradation as shown in Figure 7. Therefore, an optimum was observed near the central value of $\mathrm{pH}$, temperature and agitation speed. The optimum physical conditions for percentage phenol degradation can be attained at the 7.49 of $\mathrm{pH}$, $29.99^{\circ} \mathrm{C}$ of temperature and $138.89 \mathrm{rpm}$ agitation speed. At these optimum physical conditions maximum percentage phenol degradation of 95.12 was obtained.

\section{CONCLUSIONS}

The true functional relationship between the dependent variable $(\mathrm{pH}$, temperature and agitation speed) and maximum percentage of phenol biodegradation have been studied. The response surface methodology using $2^{3}$ full-factorial composite design was adopted to optimize these process parameters for the microbial degradation of phenol by P.putida (NCIM 2102). The optimum conditions for degradation of phenol by P.putida (NCIM 2102) were as follows: $\mathrm{pH} 7.49$, temperature $29.99^{\circ} \mathrm{C}$ and agitation speed138.89 rpm were investigated. A quadratic model was obtained for this design Statistica 6.0 version. The model employed provided good quality of predictions for the above variables in terms of effective phenol degradation and good correlation coefficient 0.9871 was obtained. By this model, we can predict the response for the above variables at any time

\section{REFERENCES}

[1] Dos Santos, V.L., De Monteiro, A.S., Braga, D.T. and Santoro, M.M. (2009) Phenol degradation by Aureobasidium pullulans FE 13 isolated from industrial effluents. Journal of Hazardous Materials, 161, 1413-1420. doi:10.1016/j.jhazmat.2008.04.112

[2] Vazquez-Rodriguez, G., Youssef, C.B. and WaissmanVilanova, J. (2006) Two-step modeling of the biodegradation of phenol by an acclimated activated sludge. Chemical Engineering Journal, 117, 245-252. doi:10.1016/j.cej.2005.11.015

[3] Entezari, M.H., Petrier, C. and Devidal, P. (2003) Sonochemical degradation of phenol in water: A comparison of classical equipment with a new cylindrical reactor. Ultrasonic Sonochemistry, 10, 103-108. doi:10.1016/S1350-4177(02)00136-0

[4] Balasankar, T. and Nagarajan, S. (2000) Biodegradation of phenols by a plasmid free Bacillus Brevis. Asian Journal of Microbiology, Biotechnology and Environmental Science, 2, 155-158. 
[5] Mahamuni, N.N. and Pandit, A.B. (2005) Effect of additives on ultrasonic degradation of phenol. Ultrasonic Sonochemistry, 13, 165-174. doi:10.1016/j.ultsonch.2005.01.004

[6] Lesko, T.M. (2004) Chemical effects of acoustic cavitation. Ph.D. Thesis, Institute of Technology, Pasadena, 2004.

[7] Santos, V.L. and Linardi, V.R. (2004) Biodegradation of phenol by a filamentous fungi isolated from industrial effluents-identification and degradation potential. Process Biochemistry, 39, 1001-1006. doi:10.1016/S0032-9592(03)00201-2

[8] Arutchelvan, V., Kanakasabai, V., Nagarajan, S. and Murali, K.V. (2005) Isolation and identification of novel high strength phenol degrading bacterial strains from phenol-formaldehyde resin manufacturing industrial wastewater. Journal of Hazardous Material, 127, 238-243.

[9] Entezari, M.H. and Petrier, C. (2004) A combination of ultrasound and oxidative enzyme: Sono-biodegradation of phenol. Applied Catalysis B: Environmental, 53, 257263. doi:10.1016/j.apcatb.2004.01.025

[10] Kobayashi, H. and Rittmann, B.E. (1982) Microbial removal of hazardous organic compounds. Environmental Science \& Technology, 16, 170A-183A. doi:10.1021/es00097a002

[11] Prpich, G.P. and Dauglis, A.J. (2005) Enhanced biodegradation of phenol by a microbial consortium in a solidliquid two-phase portioning bioreactor. Biodegradation, 16, 329-339. doi:10.1007/s10532-004-2036-y

[12] Singh. A. and Ward, O.P. (2004) Biodegradation and bioremediation. Springer, Berlin, Heidelberg, 2004.

[13] Ruiz-Ordaz, N., Ramirez, J.C.J., Castonon-Gonzalez, H., Lara-Rodriguez, A.R., Christiani-Urbina, E. and Galindez-Mayer, J. (2000) Aerobic bioprocesses and bioreactors used for phenol degradation by free and immobilized cells. In: Pandalai, S.G. Ed., Recent Research Developments in Biotechnology Bioengineering Research Signpost, Trivendrum, 83-94.

[14] Chang, S.Y., Li, C.T., Chang, M.C. and Shieh, W.K. (1998) Batch phenol degradation by Candida tropicalis and its fusant. Biotechnology and Bioengineering, 60, 391-395.

doi:10.1002/(SICI)1097-0290(19981105)60:3<391::AID -BIT17>3.0.CO;2-P

[15] Ruiz-Ordaz, N., Hernandez-Manzano, E., Ruiz-Lagunez, J.C., Christiani-Urbina, E. and Galindez-Mayer, J. (1998) Growth kinetic model that describes the inhibitory lytic effects of phenol on Candida tropicalis yeast. Biotechnology Progress, 14, 966-969. doi:10.1021/bp980095x

[16] Paller, G., Hommel, R.K. and Kleber, H.P. (1995) Phenol degradation by Acinetobacter calcoaceticus NCIB 8250 . Journal of Basic Microbiology, 35, 325-335. doi:10.1002/jobm.3620350508

[17] Hughes, E.J., Bayly, R.C. and Skurray, R.A. (1984) Evidence for isofunctional enzymes in the degradation of phenol, $\mathrm{m}$ - and p-toluate and p-cresol via catechol meta cleavage pathways in Alcaligenes eutrophus. The Journal of Bacteriology, 158, 79-83.

[18] Leonard, D. and Lindely, N.D. (1998) Carbon and energy flux constraints in continuous cultures of Alicaligenes eutrophus grown on phenol. Microbiology, 144, 241-248. doi:10.1099/00221287-144-1-241

[19] Hill, G.A. and Robinson, C.W. (1975) Substrate inhibition kinetics: Phenol degradation by Pseudomonas putida. Biotechnology and Bioengineering, 17, 1599-1615. doi:10.1002/bit.260171105

[20] Kotturi, G., Robinson, C.W. and Inniss, W.E. (1991) Phenol degradation by psychotrophic strain of Pseudomonas putida. Applied Microbiology and Biotechnology, 34, 539-543. doi:10.1007/BF00180585

[21] Folsom, B.R., Champan, P.J. and Pritchard, P.H. (1990) Phenol and Trichloroethylene degradation by Pseudomonas cepacia G4: Kinetics and interactions between substrates. Applied Environmental and Microbiology, 56, 1279-1285.

[22] Solomon, B.O., Posten, C., Harder, M.P.F., Hecht, V. and Deckwer, W.D. (1994) Energetics of Pseudomonas cepacia growth in a chemostat with phenol limitation. Journal of Chemical Technology \& Biotechnology, 60, 275-282. doi:10.1002/jctb.280600308

[23] Schroder, M., Muller, C., Posten, C., Deckwer, W.D. and Hecht, V. (1997) Inhibition kinetics of phenol degradation from unstable steady state data. Biotechnology and Bioengineering, 54, 567-576.

doi:10.1002/(SICI)1097-0290(19970620)54:6<567::AID -BIT7>3.0.CO;2-H

[24] Hoq, M.M., Soloman, B.O., Hempel, C., Rinas, U. and Deckwer, W.D. (1995) The kinetics of cellulose-free xylanase excretion by Thermomyces langiosus RT9. Journal of Chemical Technology \& Biotechnology, 63, 229236.

[25] Gopinath, S.C.B., Hilda, A., Lakshmipriya, T., Annadurai, G. and Anbu, P. (2003) Statistical optimization of amylase production by Aspergillus versicolor. Asian Journal of Microbiology Biotechnology and Environmental Science, 5, 327-330.

[26] Box, G.E.P. and Behnken, D.W. (1960) Three level design for the study of quantitative variables. Technometrics, 2, 455-475. doi:10.2307/1266454

[27] Box, G.E.P. and Hunter, J.S. (1957) Multi-factor experimental designs for exploring response surfaces. Annals of Mathematical Statistics, 28, 195-241. doi:10.1214/aoms/1177707047

[28] Cochran, W.G. and Cox, D.W. (1968) Experimental design. John Wiley and Sons, Inc., New York, 611-626.

[29] American Public Health Association (APHA), American Water Work Association, Water Pollution Control Federation (1989) Standards methods for the examination of water and wastewater. 17th Edition, Washington DC, 55 , $9-62$. 